\title{
POSSIBLE OCCURRENCE OF TOXIC AND HARMFUL PHYTOPLANKTON IN LEMBAR BAY, LOMBOK, INDONESIA
}

\author{
Boy Rahardjo Sidharta ${ }^{*, 1}$, Hilman Ahyadi ${ }^{2}$ \\ 'Biology Study Program, Faculty of Biotechnology, Atma Jaya Yogyakarta University \\ Yogyakarta, Indonesia-55281 \\ ${ }^{2}$ Biology Study Program, Faculty of Science, University of Mataram \\ Lombok, Indonesia \\ *e-mail:brsidharta@mail.uajy.ac.id
}

\begin{abstract}
Harmful Algal Bloom (HAB) incidences in Indonesian waters were increasingly occurred from time to time. Extensive and continous studies in this field are needed to be done in more areas in the country. This objective of this present survey were to determine the occurrence of potential toxic and harmful marine microalgae in Lombok, to reveal the diversity of marine microalgae found in the area, and to give some information on the occurrence of HAB phytoplankton in Lombok island. Plankton samples were taken from six stations in Lembar bay, Lombok on February, 2007. This survey found 23 marine microalgae species and two of those were potentially harmful and toxic, namely Dinophysis caudata and Gymnodinium catenatum. Four species, such as Ceratium spp, Dinophysis miles, Prorocentrum gracile, and P. micans, were noted to be harmful though so far no report on adverse effect caused by these microalgae in the area. Diatom Chaetoceros spp were the most abundant phytoplankton in almost all of the sampling areas and followed by Ceratium furca and Protoperidinium sp.
\end{abstract}

Keywords: HAB, Lombok island, Dinophysis caudata, Gymnodinium catenatum.

\section{INTRODUCTION}

Indonesia has $81,000 \mathrm{~km}$ of coastal length that is prone to many adverse effects in this area. One of the important phenomena need to be understood well in the area was the increase of cases in term of blooming of marine phytoplankton that usually give rise to affect not only marine environment, but also human health and marine-related businesses. Such a phenomenon is well known as Harmful Algal Bloom (HAB), but formerly known as red tide (Hallegraeff, 1995).

Many marine microalgae were reported to be responsible for the impact happened after $\mathrm{HAB}$ outbreak occurred in an area. Those microalgae were capable either to produce toxins and the toxins may accumulate in the muscle of marine organisms through food chain (with human being as the "last" target at the tip of the pyramid) or to damage marine ecosystems when the huge number of marine microalgae cells block the penetration of sunlight, kill fish, foul water column, etc. (Anderson, 2004).
Indonesian waters are prone to $\mathrm{HAB}$ outbreaks and some cases were reported else where (Sidharta, 2005; Damar, 2003; Wiadnyana et al. 1996; Adnan, 1989). The latest HAB outbreak was reported to happpen in Tabanan beach, Bali that took vast number of fishes killed and tourists were cancelled their trip to the beach (Anonymous, 2007).

Therefore the study on marine microalgae occurrence and regular monitoring are important factors to minimize the adverse impact of $\mathrm{HAB}$ in this country. In addition to that, there was no published report on HAB outbreak in Lombok island and its adjacent areas. The objective of this present research are: 1) to determine the occurrence of potential toxic and harmful marine microalgae in Lombok, 2) to reveal the diversity of marine microalgae found in the area, and 3) to up date information on the occurrence of $\mathrm{HAB}$ phytoplankton in Lombok (as well as in Indonesian waters). 


\section{MATERIALS AND METHODS}

Sea water samples were taken from Lembar Bay, Lombok on 15 February 2007 (Fig. 1). Plankton samples were collected utilizing plankton net and placed in small bottle. In addition to that, environmental parameters such as salinity, $\mathrm{pH}$, temperature, depth, and transparency were also measured. Samples were observed using light microscope Olympus ${ }^{\mathrm{TM}}$ type $\mathrm{CH}-2$. Plankton samples were put into the Sedgewick-Rafter counting plate and then observed under the microscope. Marine microalgae found in the counting plate were counted for individual species and were identified based on their morphology as well as their characteristics and then compared to the existing identification books such as Allen and
Cupp (1935), Tomas (1997), and Faust and Gulledge (2002).

\section{RESULTS}

This present research found 23 marine microalgae species (Table 1). Those 23 microalgae were examined and determined based on the existing work and books. These 23 species were divided into two groups namely dinoflagellates and diatoms. Thirteen species were belonged to dinoflagellate group and the rest were belonged to diatom.

Diatom species such as Bacteriastrum sp, Nitszchia sp, Pleurosigma sp, Thalassionema javanicum, T. nitszchioides, and Odontella $\mathrm{sp}$ were found in relatively low number of cells

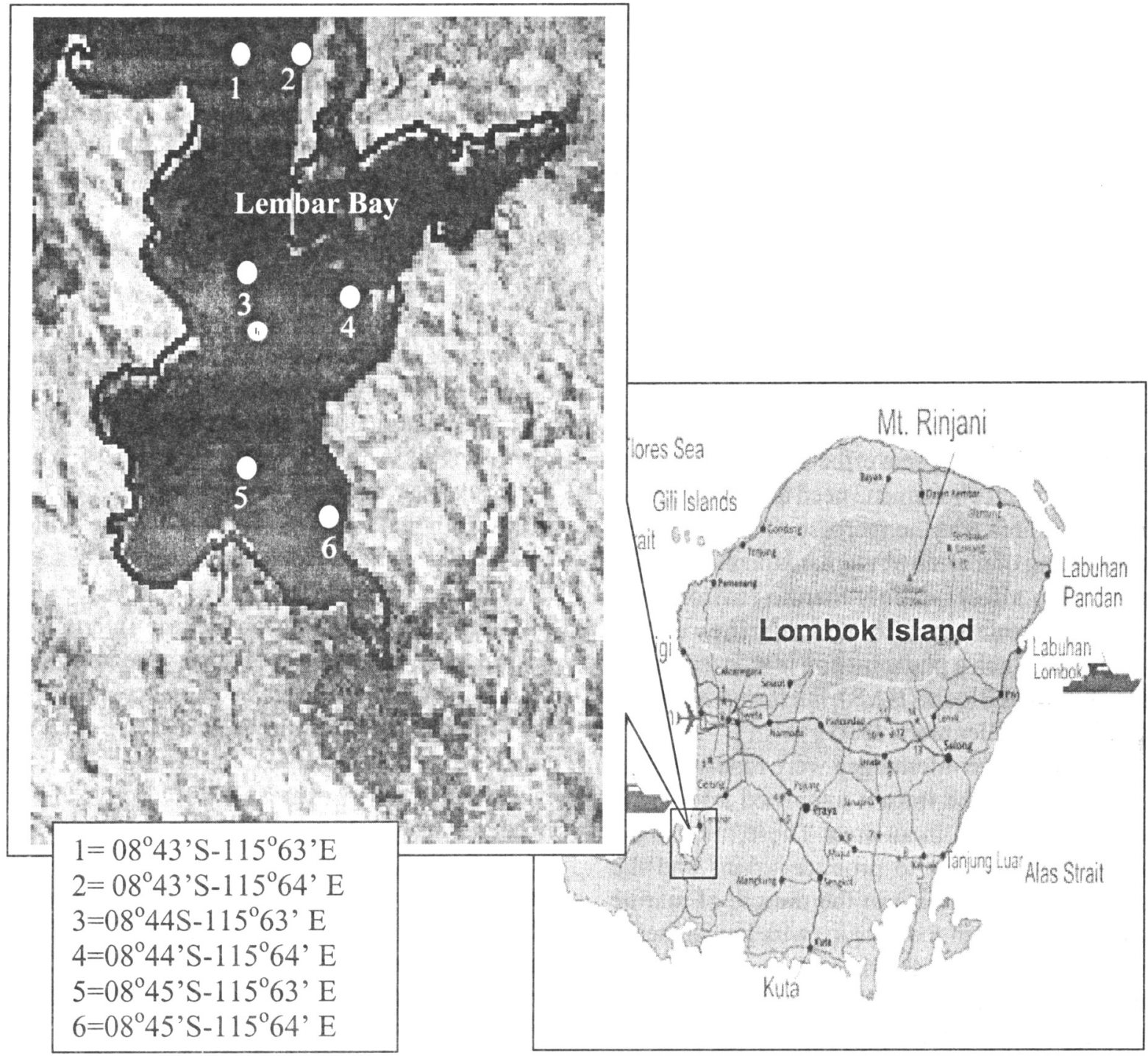

Figure 1. Map of the sampling stations in Lembar bay, Lombok island 
Table 1. Overall marine microalgae observed in the water samples

$+:$ present, - : absent

\begin{tabular}{|c|c|c|c|c|c|c|c|}
\hline \multirow{2}{*}{ No. } & \multirow{2}{*}{ Marine microalgae } & \multicolumn{6}{|c|}{ Stations } \\
\hline & & 1 & 2 & 3 & 4 & 5 & 6 \\
\hline \multicolumn{8}{|c|}{$\frac{1}{\text { Dinoflagellate }}$} \\
\hline 1. & Dinophysis caudate & + & + & + & + & + & + \\
\hline 2. & Dinophysis miles & - & + & + & - & + & + \\
\hline 3. & Gymnodinium catenatum & - & + & - & + & + & - \\
\hline 4. & Prorocentrum gracile & + & + & - & + & + & + \\
\hline 5. & Prorocentrum micans & + & + & + & + & + & + \\
\hline 6. & Protoperidinium conicum & + & + & + & + & + & + \\
\hline 7. & Protoperidinium divergens & + & + & + & + & + & $\cdot$ \\
\hline 8. & Protoperidinium leonis & + & + & + & + & + & + \\
\hline 9. & Protoperidinium pellucidum & - & + & + & + & - & + \\
\hline 10. & Ceratium furca & + & + & + & + & + & + \\
\hline 11. & Ceratium fusus & + & - & + & $\cdot$ & + & + \\
\hline 12. & Ceratium trichoceros & - & + & - & + & - & + \\
\hline 13. & Ceratium tripos & - & - & + & - & + & - \\
\hline \multicolumn{8}{|c|}{ Diatoms } \\
\hline 14. & Bacteriastrum sp & - & + & + & - & - & - \\
\hline 15. & Chaetoceros affinis & - & + & + & + & + & + \\
\hline 16. & Chaetoceros sp & + & + & + & + & + & + \\
\hline 17. & Coscinodiscus sp & + & + & + & + & + & + \\
\hline 18. & Thalassiosira sp & + & - & + & + & + & - \\
\hline 19. & Nitszchia sp & + & + & + & + & + & + \\
\hline 20. & Pleurosigma sp & - & - & + & + & - & + \\
\hline 21. & Thalassionema javanicum & + & - & - & + & - & - \\
\hline 22. & Thalassionema nitzschioides & - & + & + & + & - & + \\
\hline 23. & Odontella sp & - & - & - & + & + & - \\
\hline
\end{tabular}

(Table 2). Bacteriastrum sp, Odontella sp, and T. javanicum were the species with low frequency of occurrence, i.e. only in two stations of the area of study, while Pleurosigma sp was found in 3 stations.

\section{DISCUSSIONS}

Among the dinoflagellate group, Dinophysis caudata was known to be toxic and harmful microalgae. This species was known to be able to produce dinophysis toxin and can cause Diarrhetic Shellfish Poisoning (DSP) worldwide (Altamirano et al., 2004). As indicated in its name, the symptomps of DSP are as follows: gastrointestinal distress, nausea, vomiting, and diarrhea (Quilliam and Wright, 1995). Hence, such symptomps were very common to be misunderstood by medical practitioners, which were very similar to the adverse effect of bad sanitation in remote areas in the country. Praseno (1981) reported the bloom of $D$. caudata in Jakarta bay. Since then no more report on the bloom of this species in Indonesian waters.

Gymnodinium catenatum was also known as toxic and harmful, since this species might cause Paralytic Shellfish Poisoning (PSP) and produce saxitoxin (STX). This species, however, was found in a very few number i.e. $1 \times 10^{3}$ cells. $L^{-1}$. In addition, this species might become a problem in the area if no regular monitoring planned. The occurrence of $G$. catenatum in the area of study still need to be verified, because this species was considered as temperate and not common in the tropics (Steidinger and Tangen, 1997).

Ahyadi and Sidharta (2005) reported the occurrence of Gymnodinium sp in Bali-Lombok strait during the INSTANT cruise held. Fukuyo $e t$ al. (1993) confirmed that the same species occurred in Manila Bay, which is located in the tropical region. One possible explanation was that this species be brought into the area of study by ship's ballast water (Hallegraeff, 1995). 
Table 2. Number of cells. $L^{-1}\left(\times 10^{3}\right)$ of phytoplankton collected at the sampling sites

\begin{tabular}{|c|c|c|c|c|c|c|c|}
\hline \multirow{2}{*}{ No. } & \multirow{2}{*}{ Marine microalgae } & \multicolumn{6}{|c|}{ Stations } \\
\hline & & 1 & 2 & 3 & 4 & 5 & 6 \\
\hline \multicolumn{8}{|c|}{ Dinoflagellate } \\
\hline 1. & Dinophysis caudate & 9 & 2 & 7 & 5 & 3 & 4 \\
\hline 2. & Dinophysis miles & 0 & 2 & 5 & 0 & 5 & 5 \\
\hline 3. & Gymnodinium catenatum & 0 & 1 & 0 & 1 & 1 & 0 \\
\hline 4. & Prorocentrum gracile & 11 & 5 & 0 & 18 & 7 & 13 \\
\hline 5. & Prorocentrum micans & 4 & 6 & 4 & 4 & 5 & 6 \\
\hline 6. & Protoperidinium conicum & 61 & 67 & 188 & 78 & 76 & 89 \\
\hline 7. & Protoperidinium divergens & 8 & 53 & 33 & 15 & 36 & 0 \\
\hline 8. & Protoperidinium leonis & 14 & 31 & 23 & 12 & 11 & 24 \\
\hline 9. & Protoperidinium pellucidum & 0 & 3 & 4 & 5 & 0 & 3 \\
\hline 10. & Ceratium furca & 90 & 240 & 75 & 115 & 86 & 98 \\
\hline 11. & Ceratium fusus & 2 & 0 & 1 & 0 & 2 & 1 \\
\hline 12. & Ceratium trichoceros & 0 & 2 & 0 & 2 & 0 & 1 \\
\hline 13. & Ceratium tripos & 0 & 0 & 2 & 0 & 2 & 0 \\
\hline \multicolumn{8}{|c|}{ Diatoms } \\
\hline 14. & Bacteriastrum $\mathrm{sp}$ & 0 & 1 & 1 & 0 & 0 & 0 \\
\hline 15. & Chaetoceros affinis & 0 & 3 & 5 & 4 & 6 & 5 \\
\hline 16. & Chaetoceros sp & 21 & 320 & 98 & 125 & 76 & 87 \\
\hline 17. & Coscinodiscus sp & 12 & 22 & 14 & 16 & 23 & 17 \\
\hline 18. & Thalassiosira sp & 5 & 0 & 6 & 7 & 6 & 0 \\
\hline 19. & Nitszchia sp & 130 & 55 & 88 & 79 & 90 & 99 \\
\hline 20. & Pleurosigma sp & 0 & 0 & 3 & 4 & 0 & 4 \\
\hline 21. & Thalassionema javanicum & 2 & 0 & 0 & 2 & 0 & 0 \\
\hline 22. & Thalassionema nitzschioides & 0 & 10 & 12 & 13 & 0 & 11 \\
\hline 23. & Odontella sp & 0 & 0 & 0 & 1 & 1 & 0 \\
\hline
\end{tabular}

Two genera, Ceratium and Protoperidinium, shared the same number of species i.e. four species. Ceratium furca was non-toxic microalga, but it has been reported to be responsible for the mass mortality of blue-fin tuna at Baja, California (Orellana-Cepeda et al. 2004). C. furca could produce un-ionized ammonia with the concentration as high as $1 \mathrm{mg} . \mathrm{L}^{-1}$ and such a concentration was enough to caused rapid mortality in the tuna pens, while $C$. fusus was also reported to be able to harm invertebrate larvae though with an unknown mechanism (Taylor et al. 1995).

Two members of Prorocentrum namely $P$. gracile and $P$. micans were also known as common red tide marine microalgae in many areas (Orellana-Cepeda et al., 2004). The two were non-toxin producers, however these two species were still potentially harmful, because they might affect other marine biota when they were in very high number of cells.

There was no toxic diatom species found, but there were still some noxious species occurred such as Coscinodiscus sp that was able to produce mucus and may clog the fish gills (Altamirano et al., 2004). Chaetoceros affinis and Chaetoceros sp that have thick and hard spines were able to damage fish branchia (Altamirano et al., 2004). Both Chaetoceros species were very potential to cause harmful effect to some marine organisms, especially fish, when their number of cells reached $2 \times 10^{7}$ cells. $L^{-1}$. Furthermore, Chaetoceros spp were the most abundant microalgae found in the water samples in the area. This finding was in accordance with the survey done earlier in southern Java seas and Indian ocean by Sutomo (2003).

Thalassiosira $\mathrm{sp}$, in contrast, known as a useful diatom species in marine food chain, because this species was eaten by some zooplankton species (Orellana-Cepeda et al., 2004). Thus, the presence of this species could help to maintain the health condition of the marine ecosystem by alleviating the secondary production.

To conclude, this present research found some HAB member species in Lembar bay, Lombok. 
Some of them are really serious threat due to their ability to produce HAB toxins, i.e. Dinophysis spp and Gymnodinium catenatum. However, further research and monitoring still need to be done to verify those harmful species in the area.

Acknowledgements. The authors would like to thanks to the fishermen in Lembar Bay for providing the boat during sampling activities in the area. We wish to thanks to our chairman and deans from both universities for supporting this research.

\section{REFERENCE}

Adnan, Q. 1989. Red tides due to Noctiluca scintillans (Macartney) Ehrenb. and mass mortality of fish in Jakarta bay. In: Okaichi, T., D.M. Anderson, and T. Nemoto (eds.). Red Tides: Biology, Environmental Science, and Toxicology. Elsevier Science, pp. 5355.

Ahyadi, H. and B.R. Sidharta. 2005. Vertical and horizontal distributions of marine phytoplankton in Lombok strait during INSTANT program cruise 2004. Jurnal Segara, Vol. I(3):124-132.

Allen, W.E. and E.E. Cupp. 1935. Plankton diatoms of the Java sea. Ann. Jard. Bot. Buitenz., Vol. $X L I V(2): 101-174$.

Altamirano, R.C., A.P. Sierra-Beltran, and M.C.C. Lara. 2004. Dominance and permanence of species of harmful algal forming blooms in Mazatlan bay, Mexico (1979-2002). In: Steidinger, K.A., J.H. Landsberg, C.R. Tomas, and G.A. Vargo (eds.). Harmful Algae 2002. Florida Fish and Wildlife Conservation Commission, Florida Institute of Oceanography and Intergovernmental Oceanographic Commission of UNESCO, St. Petersburg, Florida, USA, pp. 344-346.

Anderson, D.M. 2004. The growing problem of harmful algae. Tiny plants pose a potent threat to those who live and eat from the sea. Oceanus Magazine, 43:1-3.

Anonymous. 2007. Thousands of fish killed at Tabanan beach. Kompas daily newspaper. Thursday, 1 February 2007. (In Indonesian).

Damar, A. 2003. Effects of enrichment on nutrient dynamics, phytoplankton dynamics, and productivity in Indonesian tropical waters: a comparison between Jakarta bay, Lampung bay, and Semangka bay. Ph.D. dissertation. Faculty of Mathematics and Natural Sciences, University of Kiel, Germany. Unpublished.

Faust, M.A. and R.A. Gulledge. 2002. Identifying harmful marine dinoflagellates. Smithsonian
Institution. Contributions from the United States National Herbarium, Volume 42:1-144.

Fukuyo, Y., M. Kodama, T. Ogata, T. Ishimaru, K. Matsuoka, T. Okaichi, A.M. Maala, J.A. Ordones. 1993. Occurrence of Gymnodinium catenatum in Manila Bay, the Philippines. Dev. Mar. Biol.

Hallegraeff, G.M. 1995. Harmful algal blooms: a global overview. In: Hallegraeff, G.M., D.M. Anderson, and A.D. Cembella (eds.). Manual on Harmful Microalgae. IOC Manuals and Guides No. 33. UNESCO, pp. 1-22.

Orellana-Cepeda, E., C. Granados-Machaca, and J. Serrano-Esquer. 2004. Ceratium furca: one possible cause of mass mortality of cultured blue-fin tuna at Baja, California, Mexico. In: Steidinger, K.A., J.H. Landsberg, C.R. Tomas, and G.A. Vargo (eds.). Harmful Algae 2002. Florida Fish and Wildlife Conservation Commission, Florida Institute of Oceanography and Intergovernmental Oceanographic Commission of UNESCO, St. Petersburg, Florida, USA, pp. 514-516.

Praseno, D.P. 1981. The bloom of Dinophysis caudata Kent in Jakarta Bay. Indonesia National Oceanology Institute, Indonesian Sciences Institute, pp. 139-149. (In Indonesian).

Quilliam, M.A. and J.L.C. Wright. 1995. Methods for diarrhetic shellfish poisons. In: Hallegraeff, G.M., D.M. Anderson, and A.D. Cembella (eds.). Manual on Harmful Microalgae. IOC Manuals and Guides No. 33. UNESCO, pp. 95-111.

Sidharta, B.R. 2005. The current status of research on harmful algal bloom (HAB) in Indonesia. J. Coastal Development, Vol. 8(2):75-88.

Steidinger, K.A. and K. Tangen. 1997. Dinoflagellates. In: Tomas, C.R. 1997. (ed). Identifying Marine Phytoplankton. Academic Press, San Diego. Pp. 387-584.

Sutomo, A.B. 2003. Plankton observation in the southern Java seas, Indian ocean, October 2001. Proc. Scientific Annual Meeting, Indonesian Oceanologists Association, Jakarta, 10-11 December 2003, pp. 77-81. (In Indonesian, with English abstract).

Taylor, F.J.R., Y. Fukuyo, and J. Larsen. 1995. Taxonomy of harmful dinoflagellates. In: Hallegraeff, G.M., D.M. Anderson, and A.D. Cembella (eds.). Manual on Harmful Microalgae. IOC Manuals and Guides No. 33. UNESCO, pp. 283-317.

Tomas, C.R. 1997. (ed). Identifying Marine Phytoplankton. Academic Press, San Diego. 858 pp.

Wiadnyana, N.N., T. Sidabutar, K. Matsuoka, T. Ochi, M. Kodama, and Y. Fukuyo. 1996. Note on 
occurrence of Pyrodinium bahamense in eastern Indonesian waters. In: Yasumoto, T., Y. Oshima, and Y. Fukuyo (eds.). Harmful and Toxic Algal
Blooms. Proceedings of the 7th Int. Conf. Toxic Phytoplankton, pp. 53-56. 